Acta Universitatis Nicolai Copernici • Pedagogika XXXIII/2017

Nauki Humanistyczno-Społeczne • Zeszyt 438

DOI: http://dx.doi.org/10.12775/AUNC_PED.2017.010

\title{
Wiesław Partyka
}

Instytut Pedagogiki Wydziału Nauk Społecznych KUL

\section{Surdacki, Opieka społeczna $w$ Polsce do końca XVIII wieku,}

Wyd. Towarzystwo Naukowe Katolickiego Uniwersytet Lubelskiego, Lublin 2015, ss. 650.

\begin{abstract}
mawiana monografia ma charakter pionierski. Konieczność jej napisania, jak zaznacza sam Autor, wynikała z braku całościowego ujęcia problematyki opieki społecznej w Polsce w okresie od średniowiecza do końca XVIII w. (s. 541). Praca składa się ze wstępu, trzynastu, podzielonych na podrozdziały, rozdziałów, zakończenia i bibliografii. Zastosowany został układ problemowy, a w jego ramach niekiedy chronologiczny.

Opieka społeczna na ziemiach Rzeczpospolitej Obojga Narodów w okresie staropolskim była oparta przede wszystkim o szpitalnictwo, obejmujące szpitale zakonne, prepozytury szpitalne oraz przytułki parafialne. W potrzebie można też było korzystać z pomocy bractw charytatywnych, opieki cechowej, fundacji stypendialnych dla ubogich studentów, fundacji posagowych, banków pobożnych, kas zapomogowo-pożyczkowych, dobroczynności indywidualnej, zapisów testamentowych na cele charytatywne, a także miejskich i prywatnych medyków. W opiekę społeczną dla swych poddanych zaangażowana była szlachta i magnaci. Dbano też o kształcenie ubogich uczniów i biedne panny pragnące wyjść za mąż. Wszystkie te zagadnienia zaprezento-
\end{abstract}


wane zostały szczegółowo w poszczególnych rozdziałach omawianej książki

Niezwykle ważny jest komparytystyczny aspekt analiz, ukazujący specyfikę i ogromne różnice między szpitalnictwem w Prusach Królewskich, na Warmii, Litwie, na kresach wschodnich i w centralnych rejonach Rzeczpospolitej, nie mówiąc o funkcjonujących poza strukturami państwa polskiego, szpitalach śląskich.

Praca Opieka społeczna $w$ Polsce do końca XVIII wieku, choć w bardzo dużym stopniu zredagowana na bazie opracowań, posiada też charakter badawczy. W wielu przypadkach Autor uwzględnił rezultaty dodatkowych badań archiwalnych i odwołał się bezpośrednio do źródeł, zwłaszcza normatywnych, które ukazują teoretyczne, postulowane wzorce i podstawy funkcjonowania szpitali i opieki społecznej.

Wstęp przedstawia problematykę pracy, wyjaśnia jej zakres merytoryczny, chronologiczny i terytorialny. Głównym celem, jaki postawił sobie Autor, było stworzenie zwartego, syntetycznego ujęcia dziejów opieki społecznej w Polsce, na bazie bardzo rozproszonego stanu badań, wypracowanego w ciągu stu ostatnich lat. Chciał tym samym przedstawić różne sposoby pomocy ludziom potrzebującym - poprzez ukazanie instytucji i działań charytatywnych. Istotnym i bardzo cennym elementem wstępu jest również szczegółowe omówienie dotychczasowego stanu badań w tym zakresie (co uzupełnia zamieszczona na końcu bibliografia).

W związku z tym, że system opieki społecznej na ziemiach Rzeczpospolitej Obojga Narodów w średniowieczu i w okresie staropolskim oparty był przede wszystkim o szpitalnictwo, obejmujące szpitale zakonne, prepozytury szpitalne oraz przytułki parafialne, temu właśnie zagadnieniu poświęcono cztery pierwsze rozdziały. W rozdziale pierwszym przedstawione zostały średniowieczne szpitale zakonne prowadzone zarówno przez zakony mniszo-eremickie, kanonicko-szpitalne, jak i rycersko-szpitalne. Rozdział drugi ukazuje sieć szpitali łacińskich w XVI-XVIII w. Kolejny rozdział poświęcony został szpitalom prepozyturalnym, ukazując ich rodowód i specyfikę. Zagadnienie dotyczące szpitali parafialnych, będących w dużej mierze pokłosiem postanowień Soboru Trydenckiego, opracowane zostało w rozdziale czwartym. Kolejne dwa rozdziały opisują męskie i żeńskie zakony charytatywne i ich 
działalność na ziemiach polskich od XVI do XVIII w. W rozdziale siódmym Autor nawiązuje do czterech pierwszych rozdziałów i przedstawia analizę szpitali w dwóch aspektach, pod względem ich przeznaczenia i pod względem zamieszkujących w nich osób. W rozdziale ósmym opisana została działalność bractw charytatywnych, które udzielały wsparcia bardziej doraźnego w postaci jałmużny, zapomóg, odzieży czy wyżywienia. Z nielicznymi wyjątkami nie posiadały i nie prowadziły własnych szpitali, jednak bardzo często były z nimi związane, wspierając je materialnie, pielęgnując pensjonariuszy i zaopatrując ich w wikt i niezbędne rzeczy. Ważną funkcją tych stowarzyszeń było odwiedzanie osadzonych w więzieniach oraz wspomaganie ich materialnie i duchowo. Na polu dobroczynności, szczególnie w średniowieczu, fundamentalną rolę odgrywała jałmużna, forma wsparcia ponadczasowa i najbardziej powszechna. Jej to poświęcony został rozdział dziewiąty. Autor, uwzględniając wielonarodowość i welowyznaniowość Rzeczypospolitej, przedstawił również zagadnienie szpitalnictwa i dobroczynności $\mathrm{w}$ innych wyznaniach i religiach: w Kościele protestanckim (luteranie, kalwini, bracia czescy, bracia polscy), Kościele wschodnim (prawosławnym, unickim, ormiańskim), u Żydów oraz w nielicznych enklawach wyznawców islamu. Problemowi temu poświęcono trzy ostatnie rozdziały tej pracy. Jest to najbardziej nowatorski i najmniej dotychczas opracowany aspekt opieki społecznej na ziemiach polskich.

Historia opieki społecznej i szpitalnictwa z punktu widzenia naukowego i poznawczego nie jest mniej istotnym zagadnieniem niż historia wychowania i szkolnictwa czy filozofii, a nawet literatury, które takie syntezy już od dawna posiadają. Wyraźne ostatnio ożywienie badań nad szpitalnictwem, opieką społeczną i dobroczynnością na ziemiach polskich dało Autorowi solidną podstawę do stworzenia syntetycznego ujęcia tego zagadnienia, a w konsekwencji podsumowania dotychczasowego stanu badań w tym zakresie. W pracy dokonano typologizacji i usystematyzowania szerokiej, złożonej i różnorodnej tematyki związanej z dziejami polskiej opieki i dobroczynności.

Praca ukazuje system i rodzaj opieki społecznej dla ludzi potrzebujących pomocy, organizowanej w dawnych czasach przez Kościół i inne środowiska: państwowe, miejskie oraz osoby prywatne. Zajęto się w niej problemem wszystkich kategorii ludzi nieradzących sobie 
w życiu, z uwagi na starość, kalectwo, ubóstwo, chorobę, porzucenie, sieroctwo, bezdomność itd., a także dotkniętych różnymi patologiami, jak przestępczość, prostytucja.

Choć praca dotyczy terenów Rzeczypospolitej, to jednak pokazanie opieki społecznej na ziemiach polskich zostało osadzone w kontekście i w nawiązaniu do Europy Zachodniej. Tam bowiem, zwłaszcza w Italii, Francji, a także w Ziemi Świętej, tkwią korzenie i wzorce miłosierdzia, opieki społecznej, pierwszych hospicjów i zakonów dobroczynnych, szpitali zakonnych i biskupich hospicjów oraz wielu innych zjawisk charytatywnych, które z czasem przechodziły do cywilizacji północnoeuropejskiej i państw Europy środkowo-wschodniej. Sytuacja opieki społecznej w średniowiecznym państwie polskim była w dużym stopniu odbiciem sytuacji europejskiej.

Tytułowe zagadnienie opracowano w szerokich granicach terytorialnych i chronologicznych, obejmujących czasy od początków państwa polskiego aż po jego upadek w wyniku rozbiorów. Dolną cezurę czasową wyznacza początek istnienia państwa polskiego, a dokładniej przyjęcie w 966 r. chrztu i związane z nim tworzenie się podstaw organizacji kościelnej, która stanowiła bazę do rozwoju szpitali. Górną granicę czasową wyznaczają rozbiory oraz radykalne zmiany, jakie w koncepcji dobroczynności przyniosły prądy oświeceniowe. Nowe idee i przemiany, wyrażające się w upaństwowieniu oraz laicyzacji szpitali i wykształceniu się modelu lecznicy, także szpitali specjalistycznych a urzeczywistniane przez rewolucję francuską, systematycznie rozprzestrzeniały się po całej Europie. Z tego względu zmierzch XVIII w. zamyka pewną epokę w rozwoju instytucji szpitalnych i miłosierdzia w Polsce i w Europie; stanowi cezurę, okres przejściowy między kościelnymi szpitalami szczególnie dla biednych a szpitalami nowego typu, których główną funkcją było leczenie.

Autor wyraźnie podkreśla, że pojęcie opieka społeczna posiada charakter umowny i słusznie zauważa, że aż do schyłku XVIII w. bardziej właściwe wydaje się operowanie pojęciami: miłosierdzie, działalność dobroczynna czy charytatywna, nierozłącznie kojarzonymi z doktryną chrześcijańską, która inspirowała i warunkowała kościelny przez całe stulecia charakter instytucji i działań opiekuńczych. W rozumieniu dzisiejszym termin ten pojawił się u schyłku czasów nowożytnych, 
dokładniej w Oświeceniu, kiedy opiekę zaczęto pojmować jako czysto socjalny obowiązek państwa w stosunku do swoich obywateli.

Oprócz walorów czysto naukowych, poznawczych i historiograficznych, opracowanie dziejów dobroczynności i opieki społecznej ma wartość użytkową i aplikacyjną dla takich dyscyplin, jak: pedagogika opiekuńcza, praca socjalna czy socjologia. Jest przydatne zarówno dla badaczy tych zagadnień, jak i studentów. Może przyczynić się do promocji dobrych praktyk oraz poszerzenia ogólnej wiedzy na temat dawnych form opieki społecznej dla pracowników różnych instytucji społecznych, opiekuńczych, resocjalizacyjnych, pedagogicznych, kościelnych, świeckich, państwowych, gminnych i samorządowych. Wiedza ta może im posłużyć do wykorzystania minionych doświadczeń dobroczynnych i charytatywnych, do zapobiegania i rozwiązywania współczesnych problemów i patologii związanych z ludźmi zmarginalizowanymi i wyobcowanymi społecznie.

Książka ukazuje dobre dawne tradycje charytatywne - może pomóc w wykreowaniu wrażliwości społecznej, dowartościować pracowników socjalnych i osoby pracujące z ludźmi słabszymi, powinna też zachęcić społeczeństwo do reaktywacji starych lub tworzenia nowych charytatywnych stowarzyszeń świeckich, podobnych np. do dawnych bractw czy towarzystw dobroczynności. Dzieje opieki społecznej w Polsce do końca XVIII wieku mają uniwersalny, interdyscyplinarny, wręcz humanitarny wymiar, służąc - od strony naukowej - poznaniu ważnego aspektu historii ogólnej, zwłaszcza historii społecznej, zaś od strony praktycznej - ludziom związanym z tzw. opieką społeczną czy socjalną mogą przekazywać wiele cennych wskazówek. Zainteresować też powinna środowiska wolontariatu czy Caritasu. Powodzenie idei wolontariatu czy innych działań opiekuńczych w praktyce zależy w dużej mierze od wszechstronnej formacji i świadomości historycznej ludzi w nią zaangażowanych.

Zgodnie z maksymą „historia jest nauczycielką życia” oraz zasadą „nie należy wyważać otwartych drzwi”, wiedza historyczna zawarta w tej książce może wskazać wypracowane już wcześniej wzorce i modele postępowania z ludźmi potrzebującymi pomocy. Przy dostosowaniu ich do realiów dzisiejszych i odpowiedniej modyfikacji, wiele dawnych rozwiązań można z powodzeniem zastosować aktualnie. 
